\title{
Efektivitas Model Pembelajaran Problem Solving Dan Problem Posing di Tinjau Dari Cara Berfikir Kreatif Matematika Di Sekolah Dasar
}

\author{
Teguh Adi Nugroho, Indri Anugraheni ${ }^{2}$ \\ ${ }^{1,2}$ Program Studi Pendidikan Guru Sekolah Dasar, Fakultas Keguruan Ilmu Pendidikan, Universitas Kristen Satya Wacana, \\ Jl. Diponegoro No 52-60, Jawa Tengah, Indonesia \\ 292017169@student.uksw.edu
}

\begin{abstract}
The purpose of this study was to determine the effectiveness of learning problem solving and problem posing models in terms of creative thinking in elementary school mathematics. This type of research is experimental. The technique of collecting data is by observing and testing the pretest test questions and the posttest test questions. The data analysis technique uses the normality test and the homogeneity test. From the data presented in the table above, it can be seen that the pretest mean value for the experimental class was 66.40 with a standard deviation of 8.562 using the problem posing model, the average value increased to 75.03 with a standard deviation of 5.988. In the control class, it is known that the pretest mean value of the control class is 68.83 with a standard deviation of 7.614. then given using problem solving the value increased to 80.25 with a standard deviation of 7.085. It can be concluded that the problem posing learning model is more effective in increasing students' mathematical creative thinking skills compared to the problem solving learning model.
\end{abstract}

Keywords: Problem Solving, Problem Posing, Creative Thinking Ability, Elementary School

\begin{abstract}
Abstrak
Tujuan dari penelitian ini adalah untuk mengetahui efektivitas pembelajaran model problem solving dan problem posing di tinjau dari cara berfikir kreatif matematika sekolah dasar. Jenis penelitian yang dilakukan adalah eksperimen. Teknik Pengumpulan data yaitu dengan observasi dan dilakukan uji soal tes pretest dan uji soal tes posttest. Teknik analisis data dengan uji normalitas dan uji homogenitas. Dari data yang telah di sajikan pada tabel diatas dapat diketahui bahwa nilai rata-rata pretest kelas eksperimen adalah 66,40 dengan standar deviation 8,562 dengan menggunakan model problem posing nilai rata-rata meningkat menjadi 75,03 dengan standar deviation 5,988. Pada kelas kontrol di ketahui bahwa nilai rata-rata pretes kelas kontrol adalah 68,83 dengan standar deviation 7.614. kemudian diberikan dengan menggunakan problem solving nilai meningkat menjadi 80.25 dengan standar deviation 7.085. Hal ini dapat di simpulkan bahwa model pembelajaran problem posing lebih efektif untuk meningkatkan kemampuan berfikir kreatif matematika siswa dibandingkan dengan model pembelajaran problem solving.
\end{abstract}

Kata kunci: Problem Solving,Problem Posing,Kemampuan Berfikir Kreatif,Sekolah Dasar

Copyright (c) 2021 Teguh Adi Nugroho,Indri Anugraheni

Corresponding author: Teguh Adi Nugroho

Email Address: 292017169@ sctudent.uksw.edu (Jl.Diponegoro No 52-60,Jawa Tengah,Indonesia)

Received 12 April 2021, Accepted 14 April 2021, Published 16 April 2021

\section{PENDAHULUAN}

Pendidikan di Indonesia memiliki peranan yang sangat penting dalam pembangunan Indonesia seutuhnya. Menurut UU RI Nomor 20 Tahun 2003 Tentang Sistem pendidikan Nasional, menimbang bahwa pemerintah mengusahakan dan menyelenggarakan satu sistem pendidkan nasional yang meningkatkan keimanan dan ketakwaan kepada Tuhan Yang Maha Esa serta akhlak mulia dalam rangka mencerdaskan kehidupan bangsa yang diatur dengan undang-undang.Pendidikan perlu dikembangkan dari berbagai ilmu pengetahuan, pendidikan di Indonesia sangat mempengaruhi kecerdasan suatu bangsa karena pendidikan salah satu bagian yang penting dari proses pembangunan nasional yang dapat meningkatkan pertumbuhan suatu negara (Kemendikbud, 2003). Mutu pendidikan harus diperhatikan untuk dapat mencapai tujuan pendidikan dilihat dari keberhasilan yang diraih siswa selama mengikuti 
pembelajaran di kelas.Sistem pendidikan di Indonesia masih banyak aspek yang harus dibenahi khususnya dalam pembelajaran dikelas.

Seorang guru banyak menggunakan metode yang membuat siswa merasa bosan untuk memecahkan masalah. Kemampuan yang harus dimiliki seorang guru salah satunya adalah dengan membuat perencanaan pembelajaran (RPP) dengan menarik, mampu menyajikan rencana pembelajaran dengan tepat, mampu mengadakan proses evaluasi terhadap hasil akhir pembelajaran serta mampu melaksanakan tindak lanjut. (Sukarsih, Simanjuntak, \& Triansyah, 2005) menjelaskan bahwa proses pembelajaran dari seorang guru di awali dengan kegiatan penyusunan program pengajaran atau rencana pelajaran, selanjutnya melaksanakan program atau pelaksanaan pembelajaran dan guru melakukan evaluasi atau penilaian untuk mengetahui keberhasilanya.

Hasil penelitian dari (Villela, 2013) Problem solving merupakan metode yang mengajarkan penyelesaian masalah dengan memberikan penekanan pada terselesaikanya suatu masalah secaca menalar. Problem solving membutuhkan strategi untuk dapat mengidentifikasi masalah yang menghambat pencapaian tujuan disebut juga dengan siklus problem solving. (Hidayah \& Leonard, 2013) model pembelajaran problem posing dengan pembentukan soal atau merumuskan soal dan menyusun soal. Dengan demikian problem posing dapat di artikan pendekatan dapat menekankan dalam perumusan atau pengajuan masalah oleh siswa untuk situasi atau tugas yang tersedia. Dengan pendekatan problem posing siswa di harapkan dapat mengembangkan pola piker matematika agar dapat memperbaiki kemampuan pemecahan masalah. Matematika merupakan salah satu pelajaran pokok dalam satuan pendidikan dan memegang peranan yang penting dalam pendidikan peserta didik karena matematika menggunakan metode berfikir logis,kritis,dan kreatif. Dengan demikian matematika menjadi satu mata pelajaran pokok yang wajib diikuti dan di pelajari oleh setiap peserta didik.

Pada tahun 2020 ini Indonesia dilanda pandemi covid-19. Jika kita lihat pada bulan maret tahun 2020 pada saat itu kebijakan terkait dengan pandemi silih berganti. Sebagai upaya untuk mencegah penularan virus ini, pemerintah mengeluarkan kebijakan agar sekolah meminta siswa untuk belajar dari rumah menggunakan metode secara daring. Sistem pembelajaran daring ini merupakan sistem pembelajaran tanpa tatap muka secara langsung antara guru dan siswa melainkan di ganti dengan tatap muka secara online. Hal ini sesuai dengan kebijakan Menteri Pendidikan dan Kebudayaan Republik Indonesia terkait Surat Edaran Nomor 4 tahun 2020 tentang pelaksanaan kebijakan pendidikan dalam masa darurat penyebaran corona virus disease (covid-19). Dengan demikian guru ditunut harus mampu merancang dan medesain pembelajaran yang lebih efektif dengan memanfaatkan perangkat atau media daring yang tepat dan sesuai dengan materi yang diajarkan(MENDIKBUD, 2020).

Dari uraian diatas dapat di simpulkan bahwa Mutu pendidikan harus diperhatikan untuk dapat mencapai tujuan pendidikan dilihat dari keberhasilan yang diraih siswa selama mengikuti pembelajaran secara daring. perlu adanya strategi untuk mendorong kemampuan berfikir kreatif siswa dengan adanya strategi untuk dapat mendongkrak kemampuan berfikir siswa. Menurut siswono (Siswono, 2007) salah 
Efektivitas Model Pembelajaran Problem Solving Dan Problem Posing di Tinjau Dari Cara Berfikir Kreatif Matematika Di Sekolah Dasar, Teguh Adi Nugroho, Indri Anugraheni

1005

satu cara yang dapat digunakan untuk meningkatkan kreativitas siswa dalam pembelajaran matematika adalah dengan adanya problem posing. Menurut (Pepkin, 2004) problem solving merupakan salah satu model yang melatih siswa untuk berfikir kreatif. Sistem pendidikan di Indonesia masih banyak aspek yang harus dibenahi khususnya dalam pembelajaran dikelas maka peneliti tertatik untuk melakukan penelitian dengan judul "Efektivitas Pembelajaran Probem Solving dan Problem Posing Ditinjau Dari Berfikir Kreatif Siswa Pada Pembelajaran Matematika Kelas V Sekolah Dasar”.

\section{METODE}

Penelitian ini merupakan penelitian eksperimen berikut model desain penelitian eksperimen menurut Sugiyono (Sugiono, 2011)

Tabel 1. Desain penelitian eksperimen

\begin{tabular}{|c|c|c|c|}
\hline Kelompok & Pretest & Perlakuan & Posttest \\
\hline $\mathrm{E}$ & $\mathrm{O}_{1}$ & $\mathrm{X}_{1}$ & $\mathrm{O}_{2}$ \\
\hline $\mathrm{K}$ & $\mathrm{O}_{1}$ & $\mathrm{X}_{1}$ & $\mathrm{O}_{2}$ \\
\hline
\end{tabular}

Keterangan:

$\mathrm{E} \quad=$ Kelompok eksperimen

$\mathrm{K}=$ Kelompok kontrol

$\mathrm{X}_{1} \quad=$ Perlakuan dengan menggunakan model pembelajaran tipe problem solving

$\mathrm{X}_{2} \quad=$ Perlakuan dengan menggunakan model pembelajaran tipe problem posing

$\mathrm{O}_{1} \quad=$ Pretest dari problem solving

$\mathrm{O}_{2} \quad=$ Posttest dari problem posing

Penelitian ini dilaksanakan di SDN 1 Bendoharjo dan SDN 3 Bendoharjo tahun 2021. Peneliti mengambil 2 sampel kelas tersebut karena memiliki potensi yang sama atau sejajar, Penelitian ini dilaksanakan pada tanggal 8 dan 9 februari 2021. Subyek pada penelitian ini adalah siswa kelas V yang berjumlah 35 siswa di SDN 1 Bendoharjo dan siswa kelas V yang berjumlah 24 siswa di SDN 3 Bendoharjo. Data yang di kumpulkan pada penelitian ini adalah data hasil belajar siswa berfikir kreatif pada pembelajaran matematika dengan 10 soal pretest dan 10 soal posttest. Melalui kemampuan berfikir kreatif siswa di tuntut untuk bisa memahami,meguasai,dan dapat memecahkan persoalan yang sedang di hadapinya. Penelitian ini menggunakan metode eksperimen, Pada kelompok eksperimen maupun kelompok kontrol tidak dipilih secara random. Pada kelompok eksperimen dan kelompok kontrol dilakukan tes awal. Kedua kelompok mendapatkan perlakuan yang berbeda. Dalam penelitian ini dilakukan pemberian tes berbentuk uraian bertujuan untuk mengetahui seberapa jauh peserta didik dapat memahami materi pembelajaran. Tes pertama (pretest) diberikan sebelum kedua kelompok tersebut di kenai perlakuan (treatment). 


\section{HASIL DAN DISKUSI}

\section{Uji normalitas}

Peneliti menggunakan apliasi SPSS 20 for windows untuk melakukan uji normalitas. Tujuan dari uji normalitas ini adalah untuk mengetahui penyebaran data pada kedua kelompok eksperimen maupun kelompok kontrol. Penelitian ini uji normalitas dilakukan setelah pretest dan posttest.Berikut tabel hasil uji normalitas:

Tabel 1. Uji normalitas

\begin{tabular}{|c|c|c|c|c|c|c|c|}
\hline & \multirow[t]{2}{*}{ kelas } & \multicolumn{3}{|c|}{ Kolmogorov-Smirnova } & \multicolumn{3}{|c|}{ Shapiro-Wilk } \\
\hline & & Statistic & df & Sig. & Statistic & df & Sig. \\
\hline \multirow{4}{*}{$\begin{array}{l}\text { kemampuan berpikir } \\
\text { kreatif }\end{array}$} & $\begin{array}{l}\text { pretest problem } \\
\text { posing }\end{array}$ & .097 & 35 & $.200^{*}$ & .964 & 35 & .294 \\
\hline & $\begin{array}{l}\text { posttest problem } \\
\text { posing }\end{array}$ & .107 & 35 & $.200^{*}$ & .962 & 35 & 264 \\
\hline & $\begin{array}{l}\text { pretest problem } \\
\text { solving }\end{array}$ & .134 & 24 & $.200^{*}$ & .957 & 24 & .374 \\
\hline & $\begin{array}{l}\text { posttest problem } \\
\text { solving }\end{array}$ & .129 & 24 & $.200^{*}$ & .944 & 24 & 195 \\
\hline
\end{tabular}

*. This is a lower bound of the true significance.

a. Lilliefors Significance Correction

Tabel 1 di atas menjelaskan bahwa kedua kelompok eksperimen maupun kelompok kontrol dapat di artikan jika di peroleh nilai signifikasi $<0,05$ data berdistribusi tidak normal. Maka dapat di simpulkan bahwa data berdistribusi normal. Tingkat signifikasi pretest problem posing 294 yang bearti berdistribusi normal, tingkat signifikasi nilai posttest problem posing sebanyak 264 yang bearti berdistribusi normal. Tingkat signifikasi pretest problem solving sebanyak 374 yang bearti berdistribusi normal, tingkat signifikasi posttest problem solving sebanyak 195 yang bearti berdistribusi normal.

\section{Uji Homogenitas}

Penelitian ini menggunakan SPPS 20 for windows yang bertujuan untuk dapat mengetahui sampel kelompok kelas eksperimen maupun kelompok kelas kontrol memiliki varian yang sama. Berikut adalah sajian hasil uji homogenitas:

Tabel 2. Uji homogenitas

\begin{tabular}{|c|c|c|c|c|c|}
\hline \multicolumn{6}{|c|}{ Test of Homogeneity of Variance } \\
\hline & & $\begin{array}{l}\text { Levene } \\
\text { Statistic }\end{array}$ & df1 & df 2 & Sig. \\
\hline \multirow{4}{*}{$\begin{array}{l}\text { kemampuan berpikir } \\
\text { kreatif }\end{array}$} & Based on Mean & .517 & 1 & 57 & .475 \\
\hline & Based on Median & .596 & 1 & 57 & .443 \\
\hline & $\begin{array}{l}\text { Based on Median and } \\
\text { with adjusted df }\end{array}$ & .596 & 1 & 56.128 & .443 \\
\hline & Based on trimmed mean & .540 & 1 & 57 & .465 \\
\hline
\end{tabular}


Efektivitas Model Pembelajaran Problem Solving Dan Problem Posing di Tinjau Dari Cara Berfikir Kreatif Matematika Di Sekolah Dasar, Teguh Adi Nugroho, Indri Anugraheni

1007

Tabel 2 diatas menjelaskan bahwa hasil uji homogenitas metode Levene's Test dimana memilih satu interpretasi statistic berdasarkan pada rata-rata (Based on Mean). Berdasarkan tabel menunjukan bahwa hasil uji homogenitas sebelum di perlakukan memperoleh signifikasi 0,475 > 0,05 yang bearti bahwa kedua kelompok kelas eksperimen dan kelompok kelas kontrol terdapat varian yang sama atau dapat di katakan homogen.

Tabel 3. Uji homogenitas sebelum perlakuan

Test of Homogeneity of Variance

\begin{tabular}{|c|c|c|c|c|c|}
\hline & & $\begin{array}{l}\text { Levene } \\
\text { Statistic }\end{array}$ & df1 & $\mathrm{df} 2$ & Sig. \\
\hline \multirow{4}{*}{$\begin{array}{l}\text { kemampuan berpikir } \\
\text { kreatif }\end{array}$} & Based on Mean & 1.296 & 1 & 57 & .260 \\
\hline & Based on Median & 1.366 & 1 & 57 & .247 \\
\hline & $\begin{array}{l}\text { Based on Median and } \\
\text { with adjusted df }\end{array}$ & 1.366 & 1 & 56.349 & 247 \\
\hline & Based on trimmed mean & 1.380 & 1 & 57 & .245 \\
\hline
\end{tabular}

Tabel 3 di atas menjelaskan bahwa hasil uji homogenitas menggunakan metode Levene's Test dimana dapat memilih salh satu interpretasi statistic yang berdasarkan pada rata-rata (Based on Mean). Hasil uji homogenitas sebelum di perlakuan dapat memperoleh signifikasi 0,260 dimana >0,05 dapat diartikan bahwa kedua kelas eksperimen maupun kelas kontrol mendapat varian yang sama atau dapat di katakan homogen.

Tabel 4. Uji homogenitas setelah perlakuan

\begin{tabular}{|c|c|c|c|c|c|}
\hline \multicolumn{6}{|c|}{ Test of Homogeneity of Variance } \\
\hline & & $\begin{array}{l}\text { Levene } \\
\text { Statistic }\end{array}$ & df1 & df2 & Sig. \\
\hline \multirow{4}{*}{$\begin{array}{l}\text { kemampuan berpikir } \\
\text { kreatif }\end{array}$} & Based on Mean & .517 & 1 & 57 & .475 \\
\hline & Based on Median & .596 & 1 & 57 & .443 \\
\hline & $\begin{array}{l}\text { Based on Median and } \\
\text { with adjusted df }\end{array}$ & .596 & 1 & 56.128 & .443 \\
\hline & Based on trimmed mean & .540 & 1 & 57 & .465 \\
\hline
\end{tabular}

Tabel 4 di atas menjelaskan bahwa hasil uji homogenitas menggunakan metode Levene's Test dimana memilih satu interpretasi statistic yang berdasarkan pada rata-rata (Based on Mean). Hasil dari uji homogenitas setelah dilakukan perlakuan memperoleh signifikasi 0,475 dimana > 0,05 yang bearti kedua kelompok eksperimen maupun kelompok kontrol terdapat hasil varian yang sama dan di katakan homogen.

\section{Kelas Eksperimen}

Pada penelitian di kelas eksperimen dengan menggunakan model problem posing. Pada tangal 6 februari 2021 Dengan diberikanya soal pretest terkait dengan kemampuaan awal berfikir kreatif siswa matematika kelas V di SDN 3 Bendoharjo. Peneliti melakukan penelitian ini secara daring/online peneliti mengawali dengan memperkenalkan diri melalui grub WA kelas $\mathrm{V}$, dengan menyampaikan maksud dan tujuan oleh peneliti serta memberikan soal pretest kepada semua siswa. Hasil data yang 
telah diperoleh dari soal pretest dan posttest yang terdiri dari nilai terendah,tertinggi rata-rata. Berikut adalah table hasil data kelas eksperimen:

Tabel 5. Data hasil belajar kelas Eksperimen

\begin{tabular}{|l|l|l|l|l|l|}
\hline & $\mathrm{N}$ & Minimum & Maximum & Mean & Std.deviation \\
\hline Pretes eksperimen & 35 & 51 & 83 & 66.40 & 8.562 \\
\hline Posttest eksperimen & 35 & 57 & 86 & 75.03 & 5.988 \\
\hline Valid N (listwise) & & & & & \\
\hline
\end{tabular}

Tabel 5 di atas menjelaskan bahwa nilai rata-rata pretest kelas eksperimen adalah 66,40 dengan standar deviation 8,562 dengan model pembelajaran problem posing siswa nilai rata-rata lebih meningkat menjadi 75,03 dengan standar deviation 5,988. Sebelum diberikan model pendekatan problem posing dapat dilihat nilai tertinggi yaitu 83 dan nilai terendah 51 , kemudian diberikan dengan model problem posing dapat dilihat nilai tertinggi berudah menjadi 86 dan nilai terendahnya 57.

\section{Kelas Kontrol}

Pada kelas kontrol ini penelitian dengan menggukan model pembelajaran problem solving. Menurut Wena (Wena, 2011) bahwa metode problem solving adalah melakukan operasi prosedural urutan tindakan,tahap demi tahap secara sistematis.Pada pertemuan tanggal 9 februari 2021 dengan memberikan soal pretest kepada siswa di SDN 1 Bendoharjo, pada pertemuan pertama ini peneliti di bantu dengan guru kelas untuk memberitahukan kepada siswa untuk mengambil soal pretest kemudian di kumpulkan lagi di sekolahan. Hasil data yang telah diperoleh dari soal pretest dan posttest yang terdiri dari nilai terendah,,tertinggi, rata-rata. Berikut adalah table hasil data kelas kontrol

Tabel 6. Data Hasil Belajar Kelas Kontrol

\begin{tabular}{|l|l|l|l|l|l|}
\hline & N & Minimum & Maximum & Mean & Std.deviation \\
\hline Pretes eksperimen & & 52 & 80 & 68.83 & 7.614 \\
\hline Posttest eksperimen & & 60 & 95 & 80.25 & 7.085 \\
\hline Valid N (listwise) & & & & & \\
\hline
\end{tabular}

Tabel 6 menjelaskan bahwa pada nilai rata-rata pretest kelas kontrol adalah 68,83 dengan standar deviation 7.614. kemudian model pembelajaran problem solving nilai meningkat menjadi 80,25 dengan standar deviation 7.085 sebelum diberikanya model pembelajaran problem solving nilai tertinggi yaitu 80 dan mendapat nilai terendah 52, setelah diberikan model pembelajaran problem solving ini mendapat nilai 95 dan nilai 60 .

Pada penelitian ini menggunakan model pembelajaran yaitu problem posing dan problem solving. Kedua model tersebut dapat meningkatkan kemampuan berfikir kreatif siswa dalam pembelajaran matematika. Penelitian ini terlebih dahulu dilakukan soal pretest bertujuan dapat mengetahui kemampuan berfikir kreatif awal siswa dengan model pembelajaran problem posing pada kelas eksperimen dan problem solving pada kelas kontrol. kemudian siswa di berikan soal posttest untuk dapat mengetahui peningkatan hasil belajar matematika dengan kemampuan berfikir kreatif. Dapat ditarik kesimpulan bahwa model problem posing lebih efektif dalam meningkatkan kemampuan berfikir 
Efektivitas Model Pembelajaran Problem Solving Dan Problem Posing di Tinjau Dari Cara Berfikir Kreatif Matematika Di Sekolah Dasar, Teguh Adi Nugroho, Indri Anugraheni

1009

kreatif pada pembelajaran matematika dibandingkan dengan model pembelajaran problem solving. Penelitian yang sama juga dilakukan oleh lutfi (2016) menunjukan bahwa hasil berfikir kreatif adalah sebuah kreatifitas yang memiliki tiga kritetia dan strategi yang di perlukan salah satunya dengan mengunakan strategi problem posing. kelen (2016) yang menunjukan bahwa penerapan pendekatan problem posing menjamin bahwa dalam pemnbelajaran siswa dapat termotivasi dan tertarik untuk mempelajari matematika sehingga kemampuan berfikir siswa menjadi lebih baik.

\section{KESIMPULAN}

Pada penelitian melakukan dua model pembelajaran yaitu problem posing dan problem solving, keduanya tersebut dapat meningkatkan kemampuan berfikir kreatif pada pembelajaran matematika siswa. Selain itu, penelitian ini di lakukan uji pretest untuk dapat mengetahui kemampuan berfikir kreatif awal siswa. selanjutnya diberikan dengan menggunakan model pembelajaran problem posing pada kelas eksperimen dan problem solving pada kelas kontrol. Kelas pretest eksperimen dengan rata-rata 66,40 dan posttest eksperimen rata-rata 75,03 sedangkan pada kelas kontrol pretest dengan rata-rata 68,83 dan posttest kelas kontrol 80,25.

Dari hasil penelitian ini, dapat ditarik kesimpulan bahwa model pembelajaran problem posing lebih efektif untuk meningkatkan kemampuan berfikir kreatif pada pembelajaran matematika siswa dibandingkan dengan model pembelajaran problem solving. Keberhasilan dalam meningkatkan kemampuan berfikir kreatif siswa kelas 5 dengan model pembelajaran problem posing di pengaruhi oleh kegiatan pembelajaran yang meminta siswa untuk membuat dan menjawab soal sendiri menggunakan cara yang telah ditentukan.oleh karena itu, model pembelajaran problem posing dapat digunakan atau di kembangkan pada pembelajaran di kelas. Jika belajar dengan model problem posing siswa dapat membuat permasalahan dan memecahkan soal yang mereka buat sendiri.

\section{UCAPAN TERIMA KASIH}

Terimakasih penulis ucapkan kepada seluruh pihak yang sudah membantu hingga terlaksananya penelitian ini. Terimakasih kepada Bapak/Ibu dosen yang sudah membimbing selama ini. Terimakasih kepada Bapak/Ibu Kepala Sekolah, Guru, dan siswa di SDN 1 Bendoharjo dan SDN 3 Bendoharjo yang sudah memberikan izin, dan membantu penulis dalam pelaksanaan penelitian.

\section{REFERENSI}

Faturohman, I., \& Afriansyah, E. A. (2020). Peningkatan Kemampuan Berpikir Kreatif Matematis Siswa melalui Creative Problem Solving. Mosharafa: Jurnal Pendidikan Matematika, 9(1), 107-118.

Ferdianto, F. (2014). Meningkatkan Kemampuan Pemahaman Matematis Siswa Melalui Problem Posing. Euclid, 1(1). 
Firdayanti, S. R., Artharina, F. P., \& Purnamasari, V. (2019). Keefektifan Model Pembelajaran Problem Posing Terhadap Pemecahan Masalah Matematika. Thinking Skills and Creativity Journal, 2(2), $57-62$.

Haji, S. (2011). Pendekatan problem posing dalam pembelajaran matematika di sekolah dasar. TRIADIK, 14(1), 55-63.

Hidayah, A. A., \& Leonard. (2013). Penggunaan Metode Problem Posing Dalam Proses Pembelajaran Matematika. Majalah Ilmiah Faktor, 1(1), 1-11.

Kemendikbud. (2003). Undang Undang No 20 Tahun 2003. https://doi.org/10.16309/j.cnki.issn.10071776.2003.03.004

MENDIKBUD. Surat Edaran No 4 Tahun 2020 tentang Pelaksanaan Kebijakan dalam Masa Darurat Penyebaran COVID-19. , Pub. L. No. No 4 Tahun 2020, 1 (2020).

Siswono, T. Y. E. (2007). Meningkatkan Kemampuan Berpikir Kreatif Siswa Melalui Pengajuan Masalah dan Pemecahan Masalah Matematika. Makalah Simposium Nasional 2007.

Sugiono. (2011). Metode Penelitian Kuantitatif, Kualitatif,, dan R\&D. Bandung: ALFABETA, CV.

Sukarsih, S., Simanjuntak, V., \& Triansyah, A. (2005). Peningkatan Hasil Belajar Passing Bawah Bola Voli Melalui Pendekatan Melempar Bola Pada Siswa Sd. Jurnal Pendidikan Dan Pembelajaran Khatulistiwa, 7(1), 1-11.

Villela, lucia maria aversa. (2013). Metode Problem Solving. Journal of Chemical Information and Modeling, 53(9), 1689-1699.

Wena, M. (2011). Strategi Pembelajaran Inovatif Kontemporer: Suatu Tinjauan. Konseptual Operasional. In PT. Bumi Aksara. PT. Bumi AKsara. 